\title{
Effect of Artemisia annua L. leaves essential oil and ethanol extract on behavioral assays
}

\author{
Fabio F. Perazzo, ${ }^{*, 1,3}$ Leonardo M. Lima, ${ }^{3}$ Edson Luis Maistro, ${ }^{2}$ João E. Carvalho, ${ }^{1}$ Vera L. \\ G. Rehder, ${ }^{1}$ José C. T. Carvalho ${ }^{3}$ \\ ${ }^{1}$ Centro de Pesquisas Químicas, Biológicas e Agrícolas, Universidade de Campinas, CP 6171, 13081-970 \\ Campinas-SP, Brazil, \\ ${ }^{2}$ Faculdade de Filosofia e Ciências, Departamento de Fonoaudiologia, Universidade Estadual Paulista, Av. \\ Hygino Muzzi Filho, 737, CP 181, 17525-900 Marília-SP, Brazil, \\ ${ }^{3}$ Laboratório de Pesquisa em Fármacos, Centro de Ciências Biológicas e da Saúde, Universidade Federal do \\ Amapá, Rod. JK, km 02, 68902-303 Macapá-AP, Brasil
}

\begin{abstract}
RESUMO: "Efeito do extrato etanólico bruto e óleo essencial das folhas de Artemisia annua em modelos comportamentais". Artemisia annua tem sido utilizada tradicionalmente para o tratamento de malária e febre na China devido à presença do princípio ativo, artemisinina. $\mathrm{O}$ presente trabalho avaliou a atividade central de do óleo essencial obtido por hidrodestilação e do extrato etanólico bruto de folhas frescas de A. annua em modelo in vivo como parte de um screening farmacológico dessa espécie. Sono induzido por pentobarbital, nado forçado e o ensaio de campo aberto são modelos de estudo conhecidos para o estudo de fármacos sobre depressão induzida. A administração do óleo essencial ou extrato bruto etanólico de A. annua aumentaram o tempo de imobilidade no teste do nado forçado. Por outro lado, diminuíram outros parâmetros no campo aberto, como ambulação, exploração, o ato de lamber as patas ou se lamber. Ambos produtos aumentaram o tempo de sono induzido por pentobarbital, com o óleo essencial apresentando um efeito superior ao do extrato. Pela análise dos resultados, é possível sugerir que tanto o extrato bem como o óleo essencial podem atuar como depressores do Sistema Nervoso Central (SNC).
\end{abstract}

Unitermos: Artemisia annua, Asteraceae, SNC, in vivo.

\begin{abstract}
Artemisia annua has been used as a traditional plant for the treatment of malaria and fever in China because of the presence of its active compound, artemisinin. The present study evaluated the central activity of the essential oil and the crude ethanol extract of $A$. annua L. in animals as a part of a psychopharmacological screening of this plant. The extract was prepared in ethanol (AEE) and the essential oil (AEO) obtained by hydrodistillation, both with fresh leaves. Induced immobility, the forced swimming test (FST) and the open-field test (OFT) are well-known animal models to study drug-induced depression. The administration of $A$. annua essential oil or crude ethanol extract increased the immobility time in the FST and decreased other activities (ambulation, exploration, rearing and grooming) in the OFT in animals. Both AEO and AEE prolonged pentobarbital-induced sleep as well, but the essential oil had a marked effect. Observing these results, it is possible to suggest that $A$. annua crude ethanol extract and essential oil could act as depressors on the Central Nervous System (CNS).
\end{abstract}

Keywords: Artemisia annua, Asteraceae, CNS, in vivo.

\section{INTRODUCTION}

Artemisia annua L. has been used in traditional Chinese medicine for treatment of malaria and fever because its contents of artemisinin, a sesquiterpen found in this specie and in A. apieceae in amounts enough to be used as a therapeutic agent (Klayman, 1985; Simon et al., 1990). The chemical composition of A. апnua has been studied extensively (Perazzo et al., 2003; Foglio, 1996; Carnat et al., 1985; Marques et al., 2006) and it is comprised of a complex mixture, including linalool, cineol, $p$-cymene, thujone and camphor. These compounds have been studied to evaluate its effect on the Central Nervous System (CNS), presenting a facility to cross biological membranes because of its elevated liposolubility and might affect the CNS (Robbers et al., 1996). In the present study, behavioral assays have been conducted with the essential oil (AEO) and the crude ethanolic extract (AEE) of this plant in rodents to evaluate its central effects.

\section{MATERIAL AND METHODS}

\section{Collection of the vegetal material}


A. annua L. leaves (Hybrid CPQBA 2/39 x PL5) were collected in April 2001 from the experimental field of medicinal plants of Centro Pluridisciplinar de Pesquisas Químicas, Biológicas e Agrícolas (CPQBA) - UNICAMP, located in Paulínia, SP, Brazil. A voucher specimen is deposited at CPQBA/UNICAMP, under registration number CPQBA- 12.46 .

\section{Extraction procedure}

Fresh leaves of A. annua ( $450 \mathrm{~g})$ were submitted to dynamic maceration with ethanol $(99.0 \%)$ for four hours. The macerate was filtered and this procedure was repeated. Concentration of the extracts under reduced pressure provided 51.07 g (yield 11.35\%) of crude ethanol extract (AEE). The residue was suspended in $3 \%$ Tween 80 in saline solution (100 mg AEE/mL).

\section{Essential oil extraction procedure}

The essential oil was obtained using the Method I of the Brazilian Pharmacopoeia ( $2^{\text {nd }}$ edition, 1959). Fresh leaves of A. annua (500 g) were distilled for three hours using a Clevenger apparatus, yielding $1.28 \%$. The essential oil obtained (AEO) was added to a 5\% Tween 80 in $0.9 \%$ saline solution (100 mg AEO/ $\mathrm{mL}$ ) just before administration to the animals.

\section{Animals}

Male rats (Rattus norvegicus - albinus, Wistar), specific pathogen free, weighing 150 - 200 g, acquired from the Animal Experimental Center of Universidade Estadual de Campinas were used. The animals were kept in five animal groups in polyethylene boxes, in a controlled environment $\left(23 \pm 2{ }^{\circ} \mathrm{C}\right)$, for 12 hour shifts with dark/light control, with food and water ad libitum, for 7 days before the experiments. This study was conducted according to internationally accepted principles of laboratory animal use.

\section{Treatment and dose}

The animals were treated by intraperitoneal via (i.p.), and the used doses were $470 \mathrm{mg} / \mathrm{kg}$ for the essential oil and $450 \mathrm{mg} / \mathrm{kg}$ for crude ethanol extract (Perazzo et al., 2003).

\section{Pentobarbital-induced sleeping-time}

Three groups of rats $(n=8)$ were first injected (i.p.) with the control solution (3\% Tween $800.9 \%$ in saline solution), AEO (470 mg/kg) or AEE (450 mg/kg). Thirty minutes later, $40 \mathrm{mg} / \mathrm{kg}$ of sodium pentobarbital (Cristália Ind. Farmacêutica Co.) was given i.p. and the latency time of lost reflexes and the time elapsed between the loss and recovery of the righting reflex was recorded as the sleeping time (Lima et al., 1993).

\section{Forced swimming test}

The method consists in placing a rat in cylinder (40 cm height, $18 \mathrm{~cm}$ diameter) containing $15 \mathrm{~cm}$ water maintained at $25^{\circ} \mathrm{C}$. After 15 minutes (pre-test session), the rat is dried for $15 \mathrm{~min}$ in a heated enclosure (32 ${ }^{\circ} \mathrm{C}$ ). Twenty-four hours later, the animals receive the treatment (AEO $470 \mathrm{mg} / \mathrm{kg}$, AEE $450 \mathrm{mg} / \mathrm{kg}$ ) and are exposed again to the conditions outlined above, and the total swimming time and immobility during a fiveminute period was registered in the test session (Porsolt et al., 1977). This experiment was recorded for further analysis.

\section{Open-field test}

The exploratory activity of the rats was also observed in an open-field. The AEO (470 mg/kg), AEE $(450 \mathrm{mg} / \mathrm{kg})$ or control solution were given 30 minutes before the rat has been placed into an unknown openfield $(100 \times 100 \times 50 \mathrm{~cm})$. The ambulation, exploration, rearing and grooming of the rat in the open-field were recorded for 5 minutes. This test can be used for evaluation of the effect of the drugs on the locomotor activity of the rats (Borsini et al., 1986). This experiment was also recorded for further analysis.

\section{Statistical analysis}

The statistical analyses were done using Analysis of Variance (ANOVA) followed by the TukeyKramer multiple comparison test (Sokal and Rohlf, 1995). Results with $\mathrm{p}<0.05$ were considered to be significant. Data are expressed as mean \pm S.D.

\section{RESULTS}

\section{Pharmacological assays}

In the sleeping time induced by pentobarbital, it is possible verify that the administration of both AEO $(0.8 \pm 0.37 \mathrm{~min}$.$) and AEE (4.6 \pm 0.54 \mathrm{~min}$.$) presented$ the latency time for the induction of the depressive action to be shorter than that of the control group (5.6 \pm 0.42 min.). Regarding the total sleeping time, all the groups were significantly different (Figure 1). The group treated with AEO $(219.0 \pm 7.34 \mathrm{~min}$.) presented the higher sleeping time, significantly different from the group treated with AEE $(137.5 \pm 6.39$ min.) and from the control (78.6 \pm 3.31 min.). The group treated with AEE was also different from the control group ( $<$ 0.05). These results are shown in the Figure 2.

In the FST, the administration of AEO significantly decreased the total swimming time $(0.47$ 
Table 1. Effect of i.p. administration of AEO (470 mg/kg) and AEE $(450 \mathrm{mg} / \mathrm{kg}$ ) on the total swimming time and immobility in the forced swimming test in rats.

\begin{tabular}{lccc}
\hline & Control & $\begin{array}{c}\mathrm{AEO} \mathrm{(470} \\
\mathrm{mg} / \mathrm{kg})\end{array}$ & $\begin{array}{c}\mathrm{AEE} \mathrm{(450} \\
\mathrm{mg} / \mathrm{kg})\end{array}$ \\
\hline $\begin{array}{l}\text { Swimming } \\
\text { time (min) }\end{array}$ & $4.3 \pm 0.15^{\mathrm{a}}$ & $0.47 \pm 0.86^{\mathrm{b}}$ & $3.0 \pm 0.47^{\mathrm{c}}$ \\
$\begin{array}{l}\text { Immobility } \\
(\mathrm{min})\end{array}$ & $0.2 \pm 0.15^{\mathrm{a}}$ & $4.30 \pm 1.10^{\mathrm{b}}$ & $1.2 \pm 0.21^{\mathrm{a}}$ \\
\hline
\end{tabular}

Different letters present statistically significant results $(\mathrm{p}<0.05$ - ANOVA followed by the Tukey - Kramer multiple comparison test). Data are expressed as mean \pm S.D.

Table 2. Effect of i.p. administration of AEO (470 mg/kg) and AEE (450 mg/kg) on the open-field test in rats.

\begin{tabular}{lccc}
\hline $\begin{array}{c}\text { Parameter } \\
\text { (unit) }\end{array}$ & Control & $\begin{array}{c}\text { AEO (470 } \\
\mathrm{mg} / \mathrm{kg})\end{array}$ & $\begin{array}{c}\text { AEE (450 } \\
\mathrm{mg} / \mathrm{kg})\end{array}$ \\
\hline Deambulation & $87.0 \pm 31.5^{\mathrm{a}}$ & $4.3 \pm 3.6^{\mathrm{b}}$ & $76.2 \pm 7.69^{\mathrm{a}}$ \\
Exploration & $20.8 \pm 5.60^{\mathrm{a}}$ & $0.60 \pm 0.89^{\mathrm{b}}$ & $12.6 \pm 3.43^{\mathrm{a}}$ \\
Rearing & $20.4 \pm 4.39^{\mathrm{a}}$ & $0.0 \pm 0.0^{\mathrm{b}}$ & $14.2 \pm 1.48^{\mathrm{c}}$ \\
Grooming & $20.2 \pm 9.20^{\mathrm{a}}$ & $0.0 \pm 0.00^{\mathrm{b}}$ & $5.2 \pm 0.83^{\mathrm{b}}$ \\
\hline
\end{tabular}

Different letters present statistically significant results $(\mathrm{p}<0.05$ - ANOVA followed by the Tukey - Kramer multiple comparison test. Data are expressed as mean \pm S.D.

$\pm 0.86 \mathrm{~min}$.) when compared to the control time (4.3 $\pm 0.15 \mathrm{~min}$.). The control group was different from the group treated with AEE $(3.0 \pm 0.47 \mathrm{~min}$.) as well (Table 1).

The immobility in the group treated with AEO (4.3 $\pm 1.10 \mathrm{~min}$.) was greater and statistically different from the AEE group $(1.2 \pm 0.21 \mathrm{~min}$.). In the openfield test, the AEO inhibited the locomotor activity (4.3 $\pm 3.60)$, while both AEE (76.2 \pm 7.69$)$ and the control $(87.0 \pm 31.5)$ did not show this effect. In the exploratory activity, all groups were statistically different, but the one treated with AEO $(0.60 \pm 0.89)$ presented a weak exploratory activity when compared to the control (20.8 $\pm 5.60)$ and the AEE group (12.6 \pm 3.43$)$. Results are presented in Table 2.

The number of rearing in the group treated with AEO was significantly different from the group treated with AEE (14.2 \pm 1.48$)$, and both groups were different of the control (20.4 \pm 4.39$)$. The number of grooming was greater in the control group (20.2 \pm 9.20$)$, and it was significant to the groups treated with AEO and AEE (5.2 \pm 0.83 ). These results are in Table 1 .

\section{DISCUSSION}

As a part of the pharmacological screening of this plant and its effect on the CNS, our group first described the chromatographic analysis of the AEO (Perazzo et al., 2003). Its composition includes major terpenes compounds as 1,8-cineol (20.42\%), camphor (22.68\%) and linalool (3.82\%). The major identified monoterpene compound was p-cymene (12.21\%), as

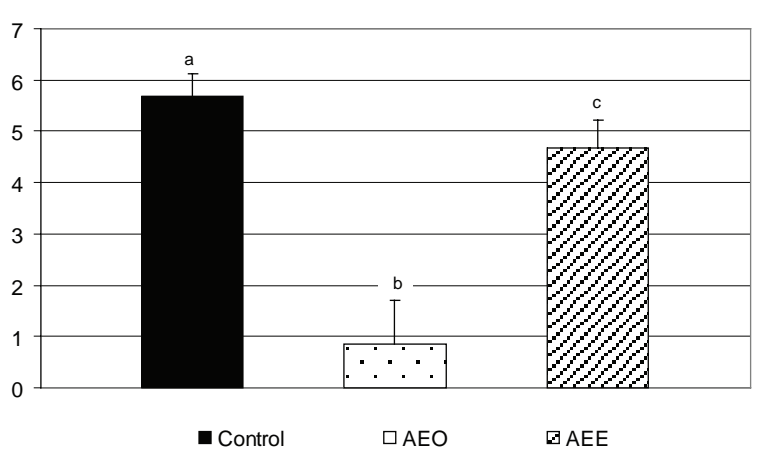

Figure 1. Effect of i.p. administration of AEO (470 mg/kg) and AEE (450 mg/kg) on pentobarbital-induced sleeping time (minutes to the lost of the righting reflex) in rats. Different letters present statistically significant results $(\mathrm{p}<0.05$ - ANOVA followed by the Tukey - Kramer multiple comparison test). Data are expressed as mean \pm S.D.

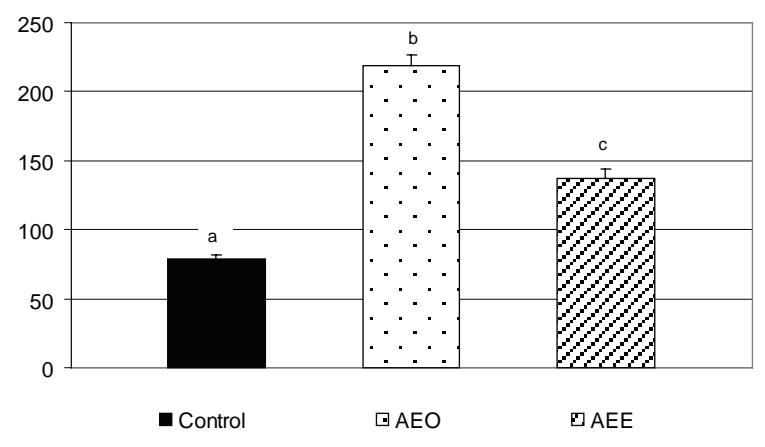

Figure 2. Effect of i.p. administration of AEO (470 mg/kg) and AEE (450 mg/kg) on pentobarbital-induced total sleeping time (minutes) in rats. Different letters present statistically significant results ( $p<0.05$ - ANOVA followed by the Tukey - Kramer multiple comparison test). Data are expressed as mean \pm S.D.

found by other authors (Carnat et al., 1985; Foglio, 1996). The major sesquiterpene compounds identified were germacrene D (3.54\%) and trans-caryophyllene (2.08\%). The AEE was analyzed to verify the common compounds. The AEE analysis showed that it was possible to identify camphor, $\beta$-cubebene and transcaryophyllene (Perazzo et al., 2003).

Regarding the pharmacological tests, the sleeping time assay evaluates the depressant activity of a drug by increasing the sleeping time induced by barbiturics. The latency time for the loss of the righting reflex was decreased in both treated groups. Total sleeping time was increased in the AEO group by $278 \%$ and the AEE also increase this time in $175 \%$, both compared to the control. The difference of the results obtained suggests that the main constituents of the essential oil, which present cineol and p-cymene, monoterpenes with depressant potential found in amounts enough to produce this action might be responsible for these results (Robbers et al., 1996). The 
AEO and AEE at the doses tested produced sedation and decreased spontaneous motor activity.

In the FST, the AEO induced a significant reduction in the immobility time compared to the AEE group, an effect that was also observed in the openfield test. This suggests that the sedation and decreased motor activity were involved in the action seen in the FST and that the effect of immobility in the FST could be central rather than peripheral origin, considering the chemical composition and polarity of each drug. This result agrees with findings of other authors (Ali et al., 1995; Ali et al., 1998).

The mechanisms by which AEO and AEE act out remain unclear. However, the present results obtained with AEO and AEE suggest that both may contain several active compounds acting on the CNS by different paths.

Cholinergic drugs may cause an increase in the immobility time in FST and decrease ambulation on an open-field (Bartholini et al., 1985; Herman et al., 1981), whereas cholinomimetics increase it (Herman et al., 1981). The administration of AEO increased the immobility time, and that may be explained by an increase in cholinergic activity, as described in our previous study (Perazzo et al., 2003).

Antidepressant drugs, such as fluoxetine (serotoninergic agents), increase the total swimming time, decreasing immobility time (Kirby \& Lucki, 1997), just as dopaminergics (Duncan et al., 1985; Kitada et al., 1986), knockout mice for dopamine receptor (Dulawa et al., 1999) or noradrenergic drugs (Porsolt et al., 1977).

In the OFT, decreases in ambulation, exploration, rearing and cleaning are signs of the depressant activity of the drugs (Borsini et al., 1986). When the animals were submitted to this test, it was noted that the treatment with AEO inhibited the motor activity when compared to the control group. On the other hand, treatment with AEE did not show a significant difference in this activity. The AEO decreased all of these parameters when compared to the control, probably because of its chemical composition.

The results found in this study show that the AEE presented different activities when compared to AEO, especially in the ambulation and exploration. This difference could be attributed to the different compounds present in AEO and AEE. According to the results, it is possible to suggest that the AEO has a marked depressant potential, and the AEE does not.

\section{ACKNOWLEDGEMENTS}

We are thankful to Dr. Warren Hill Kelly (Olemiss Writing Center) for the English revision of this manuscript.

\section{REFERENCES}

Ali BH, Bashir AK, Banna NR, Tanira MOM 1995. Central nervous system activity of Rhazya stricta Decne in mice. J Exp Pharmacol Physiol 22: 248-253.

Ali BH, Bashir AK, Tanira MOM 1998. The effect of Rhazya stricta Decna, a traditional medicinal plant, on the forced swimming test in rats. A new model sensitive to antidepressant treatments. Pharm Biochem Behav 59: 547-550.

Bartholini G, Lloyd KG, Scatton B, Zivkovic B, Morselli PL 1985. The GABA hypothesis of depression and antidepressant drug action. Psychopharmacol Bull 21: 385-387.

Borsini F, Evangelista S, Meli A 1986. Effect of GABAergic drugs in the behavioral despair test in rats. Eur $J$ Pharmacol 121: 265-268.

Carnat AP, Gueugnot J, Lamaison JL, Guillot J, Pourrat H 1985. Ann Pharm Françaises 43: 397-405.

Dulawa SC, Grandy DK, Low MJ, Paulus MP, Geyer AG 1999. Dopamine D4 knock-out mice exhibited reduced exploration of novel stimuli. J Neurosci 19: 9550-9556.

Duncan GE, Paul IA, Harden TK, Mueller RA, Stumpf WE, Bresse GE 1985. Rapid down regulation of beta adrenergic receptors by combining antidepressants drugs with forced swim: a model of antidepressantinduced neural adaptation. J Pharmacol Exp Ther 234: 402-408.

Foglio MA 1996. Estudo químico da Artemisia annua L. aclimatada no Brasil. Campinas, 475p. Tese de Doutorado - Instituto de Química, Universidade Estadual de Campinas.

Herman ZS, Plech A, Bien E, Wieloch-Depta L, Jez W 1981. Effect of cholinomimetics, cholynolitics and atypical antidepressants in the behavioral despair test in the rat. Pol J Pharmacol Pharm 33: 485-489.

Kirby LG, Lucki I 1997. Interaction between the forced swimming test and fluoxetine treatment on extracelular 5 - hydroxytryptamine and 5-hydroxyindolacetic acid in the rat. J Pharmacol Exp Ther 282: 967-976.

Kitada Y, Miyauchi T, Cosaza T, Satoh S 1986. The significance of $\beta$ - adrenoceptor down regulation in the desipramine action in the forced swimming test. NS Arch Pharmacol 333: 31-35.

Klayman DL 1985. Qinghaosu (artemisinin): an antimalarial drug from China. Science 228: 1049-1055.

Lima TCM, Morato GS, Takahashi RN 1993. Evaluation of the central properties of Artemisia verloturum. Planta Med 59: 326-329.

Marques DA, Foglio MA, Morgante PG, Sluys MAV, Shepherd SLK 2006. Biotechnology approaches for production of antiulcerogenic dihydro-epideoxyarteannuin B isolated from Artemisia annua L. Rev Bras Farmacogn 16: 291-299.

Perazzo FF, Carvalho JCT, Carvalho JE, Rehder VLG 2003. Central properties of the essential oil and the crude ethanol extract from aerial parts of Artemisia annua L. Pharmacol Res 48: 497-502.

Porsolt RD, LePichon M, Jalfre M 1977. Depression: a new animal model sensitive to antidepressant treatment. Nature 266: 730-732.

Robbers JE, Speedie MK, Tyler VE 1996. Pharmacognosy and Pharmacobiotechnology. New York: Williams \& Wilkins.

Simon JE, Denys C, Cebert E, Grant L, Janick J, Whipkey A 1990. Artemisia annua L. A promising aromatic and medicinal. Advances in new crops: Proceedings of the First National Symposium New Crops: research, develop and economics, 522-526.

Sokal RR, Rohlf FJ 1995. Biometry, San Francisco: W.H. Freeman. 